\title{
$A A$ FROM LOMAS FORMATIONS. A NEW ORCHIDACEAE RECORD FROM THE DESERT COAST OF PERU
}

\author{
Delsy Trujillo ${ }^{1,3}$ and Amalia Delgado RodríGueZ ${ }^{2}$ \\ ${ }^{1}$ Research Associate, Herbario MOL, Facultad de Ciencias Forestales, Universidad Nacional Agraria \\ La Molina. Av. La Universidad s/n. La Molina. Apartado 12-056 - Lima, Perú. \\ ${ }^{2}$ Laboratorio de Dicotiledóneas. Museo de Historia Natural, Universidad Nacional Mayor de San Marcos. \\ Av. Arenales 1256. Jesús María - Lima, Perú. \\ ${ }^{3}$ Corresponding author: delsytrujillo@gmail.com
}

\begin{abstract}
Orchid species of the genus $A a$ have been described as mostly restricted to high elevations zones in the Andes and mountains of Costa Rica. Here, we record populations of Aa weddelliana at lower elevations in lomas formations from the desert coast of Peru; this is the fourth species of Orchidaceae registered in Peruvian lomas. Furthermore, we illustrate and discuss some floral features of Aa weddelliana.

Resumen. Las especies del género $A a$ han sido descritas como orquídeas restringidas generalmente a zonas altas de los Andes y montañas de Costa Rica. Se presenta el registro de poblaciones de Aa weddelliana a elevaciones más bajas, en formaciones de lomas en la costa desértica del Perú, siendo ésta la cuarta especie de Orchidaceae registrada para las formaciones de lomas. Asimismo, ilustramos y discutimos algunos aspectos florísticos de $\mathrm{Aa}$ weddelliana.
\end{abstract}

Keywords / Palabras clave: Orchidaceae, Peru, Lomas formations, Desert, $A a$

The western coast of South America between Peru and Chile $\left(5^{\circ}-30^{\circ} \mathrm{S}\right.$ latitude $)$ is occupied by a continuous belt of desert of $3500 \mathrm{~km}$ long and a surface area of about $2900 \mathrm{~km}^{2}$. Its aridity is mainly due to the Humboldt Current and the South Pacific anticyclone (Rundell et al. 1991). A combination of climate factors on the coast during winter (June-September) allows the formation of thick fog masses in the ocean. Fog comes into the continent and is intercepted by foothills near the sea, creating ample water for vegetation to flourish for a period of months. This peculiar habitat is called lomas formations and is unique in its plant community (Weberbauer 1945, Oka \& Ogawa 1984, Ferreyra 1993, Dillon et al. 2003). Lomas formations occur in the desert as "fog oases" or "islands of vegetation" in disconnected localities along the coast of Peru and Chile, at elevations that generally do not exceed the $1000 \mathrm{~m}$. In Peru, it has been identified in over 70 localities ranging from Trujillo $\left(8^{\circ} \mathrm{S}\right.$ latitude) to Tacna $\left(18^{\circ} \mathrm{S}\right.$ latitude). These localities are composed of a variable mixture of annuals, short-lived perennials and in some cases even woody vegetation (Dillon et al. 2003). Some years are affected by ENSO (El Niño
Southern Oscillation) events, where the occurrence of unusual precipitations during summer (DecemberMarch) alters the normal cycle of vegetation, allowing for the development of vegetation during this period.

The genus $A a$ Rchb.f. includes terrestrial orchids with tiny and non-resupinate flowers distributed from Venezuela to the north of Chile and Argentina with a disjunct population in Costa Rica. Although some authors have claimed the distribution of $A a$ in South America is restricted to the highest zone of the Andes (i.e. above 3100 m.a.s.1.; Wood 2003, Álvarez-Molina $\&$ Cameron 2009), there are some populations of $A a$ at lower elevations. For instance, Aa achalensis Schltr. reaches $700 \mathrm{~m}$ of elevation in north-central Argentina (Cucucci 1964).

The revision of the orchid collection at USM and recent field work in the Southern Peruvian lomas reveal the presence of populations of $A a$ at elevations between 300 to $1000 \mathrm{~m}$ in four lomas formations from $11^{\circ} 21^{\prime} \mathrm{S}$ to $15^{\circ} 46^{\prime} \mathrm{S}$ latitude: Lomas de Lachay National Reserve, Department of Lima; a locality at south of Nazca, Department of Ica (the exact locality was not recorded by the collector); and Los Cerrillos 
and Lomas de Atiquipa, Department of Arequipa (Fig 1,2). Except for the different size of the flowers - the larger flowers are from the more southerly lomas specimens- all the specimens studied correspond to Aa weddelliana (Rchb.f.) Schltr. (Fig 3,4). Previously, this species has only been recorded at elevations between 2700-3800 m in Peru, Bolivia and Argentina (Schweinfurth 1958, Tropicos.org 2010).

To the best of our knowledge, there are no previous records of Orchidaceae from the Departments of Ica and Arequipa. Therefore, A. weddelliana is the first record from these departments. Nevertheless, it is not the only orchid recorded from the Peruvian lomas formations (Fig 1). Previous authors have identified plants of Chloraea pavonii Lindl. in Lomas de Chancay and Amancaes; and Malaxis andicola (Ridl.) O. Ktze. in Cerro Cabras (Schweinfurth 1958, 1959, Correa 1969, Garay \& Romero-González 1998). The revision of herbaria collections also shows the presence of Pelexia matucanensis (Kraenzl.) Schltr. in Cerro Campana, Cerro Cabras and Casma (A.Lopez 710, HUT; N. Angulo 765, HUT and Ferreyra 8049, MOL respectively). Like $A$. weddelliana, most of the records of C. pavonii, M. andicola and P. matucanensis came from the localities of middle to high elevation of the Andean Cordillera (Bennett \& Christenson 1998, Schweinfurth 1958).

The origin of vascular plant species within lomas formations have been grouped into 4 categories: (1) pan-tropical or weedy species, (2) long-distance disjunctions from the Northern Hemisphere desert, (3) species disjunct from the adjacent Andean Cordillera, and (4) plants restricted to the coastal desert (Dillon et al. 2003, 2009). The origin of orchid species in lomas formations likely belongs to the third category.

Álvarez-Molina and Cameron (2009) point out several morphological traits found in plants of $A a$ as Myrosmodes Rchb.f. ( $A a$ 's closely related genus and also considered a high elevation specialist of the Andes) that allow them to cope with the moist, freezing, and windy environments of the paramos and the arid conditions of the puna. Probably, equivalent traits will also allow A. weddelliana to develop in the harsh conditions of lomas, especially the fluctuations between arid and humid conditions and strong winds that come from the sea.

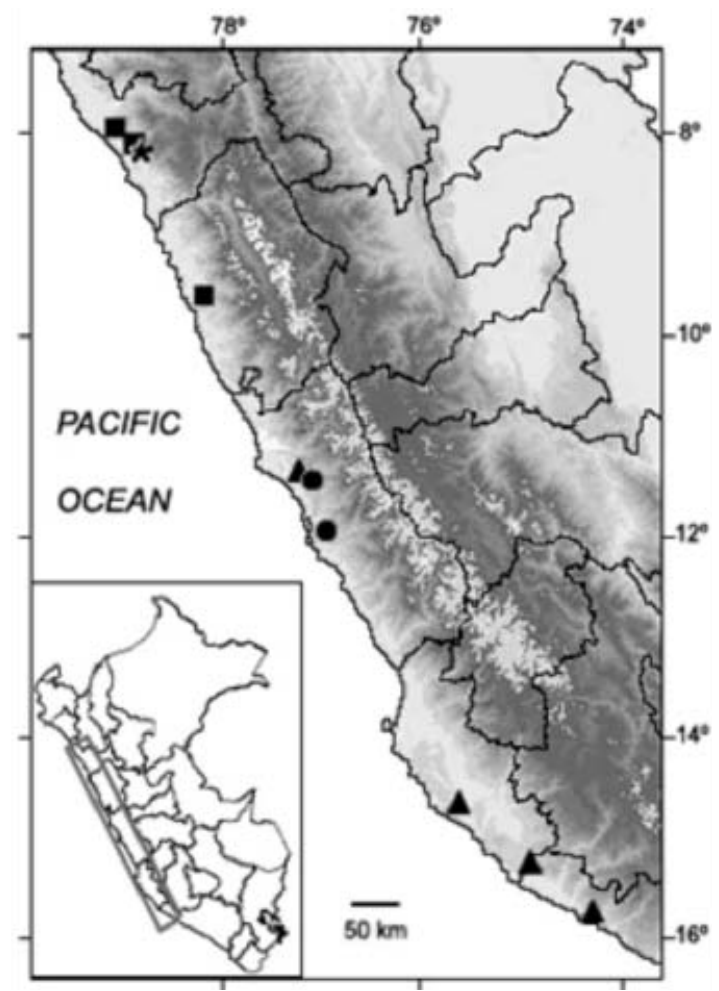

Figure 1. Map including Peruvian lomas formations localities where Orchidaceae species have been recorded. Aa weddelliana (triangle), Chloraea pavonii (circle), Malaxis andicola (asterisk), Pelexia matucanensis (square).

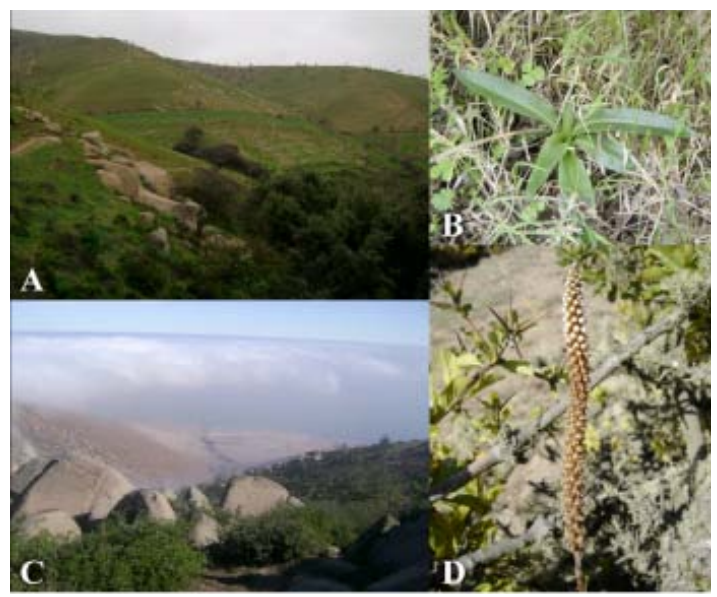

Figure 2. Aa weddelliana in the Lomas de Atiquipa, Department of Arequipa. A. Panoramic view of Lomas de Atiquipa during winter. B. Plant of Aa weddelliana. C. Habitat of Aa weddelliana in Lomas de Atiquipa. D. Inflorescence of Aa weddelliana. Photographs by Amalia Delgado. 

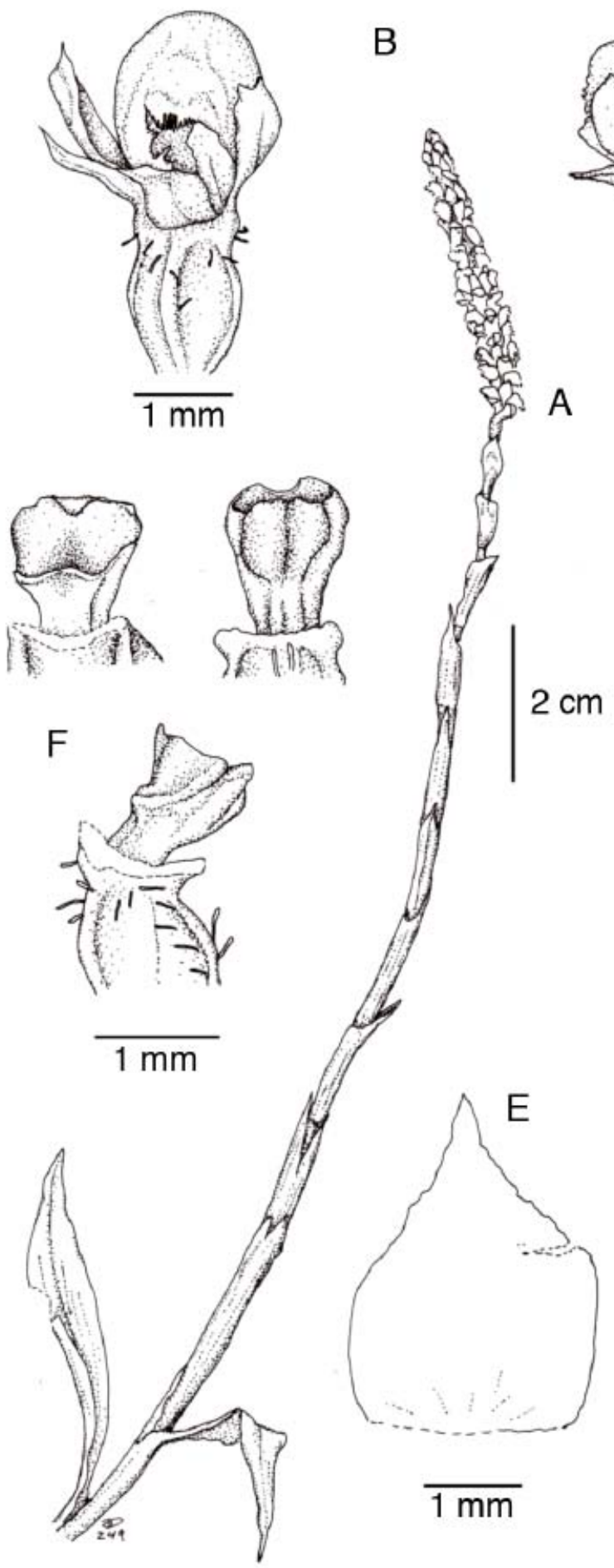

A
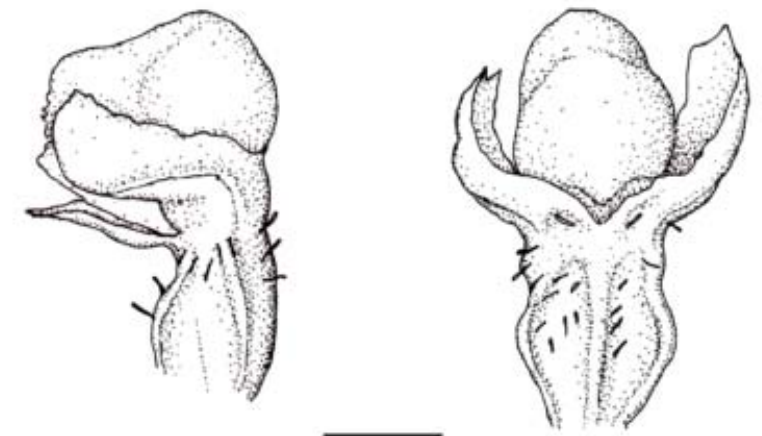

\section{$\overline{1 \mathrm{~mm}}$}
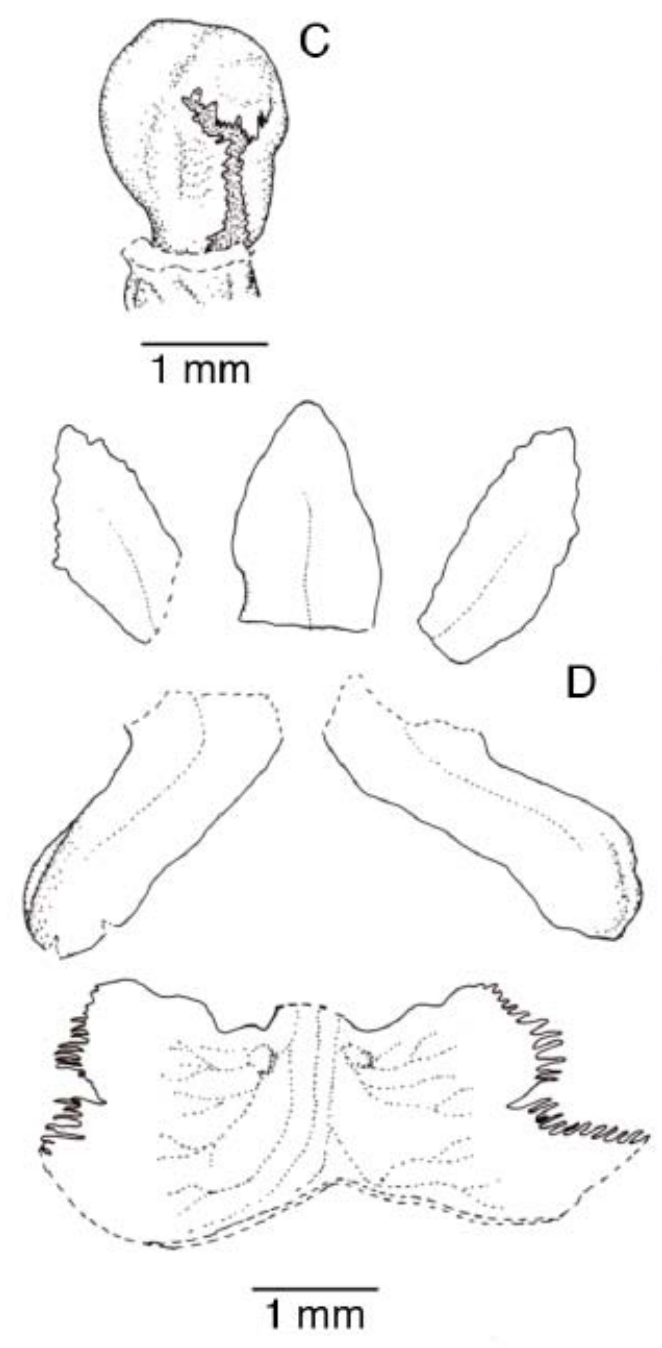

Figure 3. Aa weddelliana. A. Habit. B. Flower, three views. C. Lip in natural position. D. Dissected perianth. E. Floral bract.

F. Column, three views. Drawing by D. Trujillo based on K. Rahn 198, USM. 

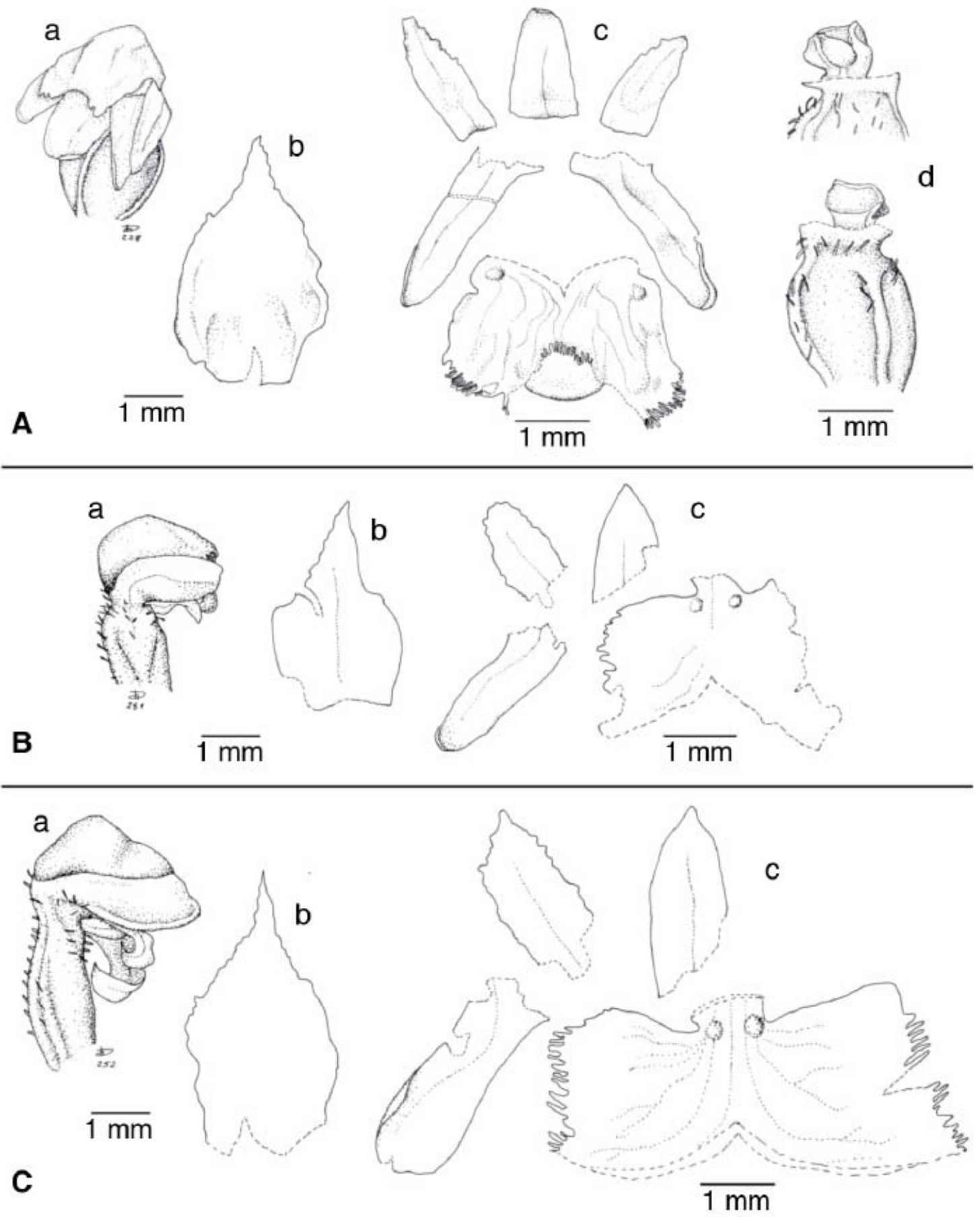

FiguRE 4. Comparison of the flowers of Aa weddelliana. A. Flower from the holotype (G. Mandon 1167, W). B. Flower of a plant from Lomas de Lachay (A. Cano 710, USM-161164). C. Flower of a plant from Lomas de Atiquipa (R. Ferreyra 14034, USM). a- Flower. b- Floral bract. c- Dissected perianth. d- Column, ventral and dorsal view. Drawing by D. Trujillo. 
Regardless, more field work and a careful examination of $A a$ material from the herbarium collection are necessary in order to document the real distribution of A. weddelliana, its ecology, morphological diversity and adaptations to different environments.

The following description of $A$. weddelliana was based on the type material and specimens from the lomas formations studied in the present work.

Aa weddelliana (Rchb.f.) Schltr., Repert. Spec. Nov. Regni Veg. 11: 150. 1912. Altensteinia weddelliana Rchb. f.. Xenia Orchidacea 3: 19. 1878.

TYPE: Bolivia, Vicinity Soratta. Paracollo, in Scritosis. 3400 m. December 1856-January 1857. Mandon 1167 (holotype: W; isotype: G,K). Fig. $4 \mathrm{~A}$.

Plant small, terrestrial herb. Roots fasciculate, fleshy. Leaves (present before flowering) forming a basal rosette, narrowly oblong, acute to acuminate, up to $11.0 \times 1.7 \mathrm{~cm}$. Inflorescence slender, erect, up $50 \mathrm{~cm}$ long, enclosed by 10 to 13 diaphanous sheaths, terminated in a densely many flowered cylindrical spike of 4-12 cm long, rachis of the spike sparsely pilose. Floral bracts ovate, acute to acuminate, margins slightly erose, reflexed, 4-6 × 2.5-3.0 mm, somewhat surpassing the flowers. Flowers non-resupinate, white with pink-brown tones. Dorsal sepal oblong-ovate, acute, 1-nerved, 1.5-2.5 x 0.8-1.0 mm. Lateral sepals shortly connate at the base, obliquely oblong, obtuse, dorsally hairy at the base, apex slightly erose, 1-nerved, 2.5-3.0 $\times$ 0.7-1.0 mm. Petals falcate-ligulate, obtuse to acute, margin variable erose (mostly the distal half), 1-nerved, 1.6-2.7 x 0.7-1.0 mm. Lip calceolate, the opening slightly projected toward, transverse, entire to obscurely 3-lobed, margins lacerate, base with two calli, $4 \mathrm{~mm}$ wide when expand. Column short, retuse rostelum, $0.7-1.5 \mathrm{~mm}$ long, straight in young flowers and bent in old flowers. Stigma quadrate in young flowers and transversely elongate in old flowers.. Ovary subcylindric, hairy, 2.0-2.5 mm long.

Material studied: PERU. Arequipa: Caravelí, Arajaipampa, Lomas de Atiquipa, $980 \mathrm{~m}$ en suelo franco arcilloso, creciendo bajo el refugio de Cytharexylum flexuosum, flores blancas, 16 febrero 2008, A. Delgado 4021. Caravelí, lomas de Los Cerrillos, entre Nazca y Chala, $700 \mathrm{~m}$, habitat rocoso, sépalos y pétalos rosado- parduzcos, labelo blanquecino, 23 setiembre 1958, $R$. Ferreyra 13455, USM. Caravelí, encima de Atiquipa, sobre rocas, 600-700 m, flores blancas, 20 diciembre 1959, R. Ferreyra 14034, USM (illustration voucher, Fig. 4C). Ica: Nazca, km 52.4 al sur de Nazca, entre rocas, 18 octubre 1957, K. Rahn 198, USM (illustration voucher, Fig. 3). Lima: Huaura, Lomas de Lachay, suelo arenoso, con zonas pedregoso-rocoso, 300-700 $\mathrm{m}$, hierba epífita, escasa, sólo frutos secos, 23 febrero 1996, A. Cano et al. 7101, USM-166101. Chancay, Lomas de Lachay, Km 105 carretera Panamericana Norte, suelos arenosos, arenoso-arcillosos, con partes pedregosas y rocosas, 300-700 $\mathrm{m}$, hierba epífita, escasa, solo frutos secos, 24 febrero 1996, A. Cano et al. 7101, USM-161164 (illustration voucher, Fig. 4B).

Other ReCords: PERU. Ica: Ica, Santiago, Lomas de Amara - Ullujalla, loma con gran captación de humedad de neblina y vientos fuertes, $834 \mathrm{~m}$, suelo arenoso semidescubierto con parches dispersos, 7 diciembre 2007, A. Orellana \& O. Whaley 353 (digital photo).

Distribution: Central and southern coast of Peru, Bolivia and North Argentina, between 300 and 3800 $m$ of elevation.

Habitat and ECOLOGy: In sandy, sandy-clay, stony and rocky soils of lomas formations, paramos and puna. Occasionally plants of $A$. weddelliana can grow on decaying tree trunks in the lomas formations and is recorded as epiphyte (personal communication with the collector of $A$. Cano 7101). Flowering from September to February.

In the original description of $A$. weddelliana, Reichenbach (1878) indicated that the floral bracts are shorter than the flower and 5-lobed rostellum. However, after examination of the type material in W (Fig 4A.), it was found that when the floral bracts -reflexed in natural position- are expanded and measured, they are longer than the flower. The rostellum is without lobes; the appearance of lobes must be a deformation created during the preparation of the herbarium material or the rehydration of the flower for study. Two floral features were also noticed during the present study that were neither mentioned in the original description of Reichenbach, nor in the work of Schweinfurth (1958): petals with erose margin and ovary hairy. 
ACKNOWLEDGEMENTS. We want to thank to the curators of W and USM for having allowed us access to study the herbarium material and to rehydrate some of the specimens mentioned here. To Jose Roque for his help in the map elaboration. To William R. Morrison III for his suggestions on improving the manuscript. To the Lomas de Atiquipa's inhabitants for their logistical support. And, to Oliver Whaley and Alonso Orellana for sharing their photographic records of Lomas de Amara.

\section{Literature Cited}

Álvarez-Molina, A. \& K.M. Cameron. 2009. Molecular phylogenetics of Prescottiinae s.l. and their close allies (Orchidaceae, Cranichideae) inferred from plastid and nuclear ribosomal DNA sequences. Amer. J. Bot. 96: 1020-1040.

Bennett, D.E. \& E.A.Christenson 1998. Chloraea pavoni Lindl. Icones Orchid. Peruv. pl. 425.

Cocucci, A.E. 1964. The life-history of Aa achalensis Schlechter (Orchidaceae) Phytomorphology 14: 588597.

Correa, M.N. 1969. "Chloraea" género sudamericano de Orchidaceae. Darwiniana 15:374-500.

Dillon, M.O., M. Nakazawa \& S. Leiva. 2003. The lomas formations of coastal Peru: composition and biogeographic history. Pp. 1-9 in: J. Haas \& M.O. Dillon (eds.), El Niño in Peru: biology and culture over 10,000 years. Fieldiana Bot. 43 .

Dillon, M.O., T. Tu, L. Xie, V. Quipuscoa \& J. Wen. 2009. Biogeographic diversification in Nolana (Solanaceae), a ubiquitous member of the Atacama and Peruvian deserts along the western coast of South America. J. Syst. Evol. 47: 457-476.

Ferreyra, R. 1993. Registros de la vegetación en la costa peruana en relación con el Fenómeno El Niño. Bull. Inst. fr. etudes andines. 22: 259-266.

Garay, L.A. \& G. Romero-González. 1998. Schedulae Orchidum. Harvard Pap. Bot. 3: 53-62.

Oka, S. \& H. Ogawa. 1984. The distribution of lomas vegetation and its climatic environments along the Pacific Coast of Peru. Geogr. Rep. Tokyo metrop. Univ. 19:113-125.

Reichenbach, H.G. 1878. Orchideae Mandonianae. Xenia Orchid. 3: 17-19.

Rundell, P.W., M.O. Dillon, B. Palma, H.A. Mooney, S.L. Gulmon \& J.R. Erlenberg. 1991. The phytogeography and ecology of the coastal Atacama and Peruvian deserts. Aliso 13: 1-49.

Schlechter, R. 1912. Die Orchideen Gattungen Altensteinia HBK, Aa Rchb.f. und Myrosmodes Rchb.f.. Repert Spec. Nov. Regni Veg. 11: 147-150.

Schweinfurth, C. 1958. Orchids of Peru. Fieldiana Bot. 30: $1-260$.

Schweinfurth, C. 1959. Orchids of Peru. Fieldiana Bot. 30: 261-531.

Tropicos.org. 2010. Missouri Botanical Garden. http:// www.tropicos.org/Name/23505925. Accessed 08 Nov 2010.

Weberbauer, A. 1945. El mundo vegetal de los Andes peruanos. Estudio fitogeográfico. Lima. Ministerio de Agricultura.

Wood, J. 2003. Aa. Pp. 24-26 in: A.M. Pridgeon, P.J. Cribb, N.W. Chase \& F.N. Rasmussen (eds.), Genera Orchidacearum, 3: Orchidoideae part 2, Vanilloideae. Oxford University Press, Oxford. 